ISSN 2413-0877 Volume 1 (2015)

The 1st International Symposium on Aquatic Product Processing 2013

\title{
CARRAGEENAN AS BINDER IN THE FRUIT LEATHER PRODUCTION
}

\author{
Dina Fransiska, Siti Nurbaity Kartika Apriani, Murdinah, Susiana Melanie \\ Jl. KS Tubun Petamburan VI, Slipi, Jakarta Pusat \\ *e-mail: frans_dina@yahoo.com
}

\begin{abstract}
Research on the production of mango fruit leather with the addition of carrageenan as the binder has been conducted. The fruit leather production process needs ripe and fresh mango. Carrageenan which was used as the binder was produced from the extraction of seaweed Eucheuma cottonii. The concentrations of carrageenan that used were $0 \%, 0,2 \%, 0,4 \%$ and $0,6 \%$ by using gelatin as a comparison. The fruit leather ingredients are puree mango, sugar, sorbitol, and carrageenan. The analysis was conducted to the carrageenan as the binder and the fruit leather as a product. The parameters which were analyzed were moisture content, ash content, acid insoluble ash content and gel strength. The mango fruit leather was analized in terms of moisture content, water activity $(\mathrm{Aw})$, organoleptic hedonic test and hedonic quality. The result showed that carrageenan had a fairly high strength gel $1322 \mathrm{~g} / \mathrm{cm}^{2}$. Based on the result of the organoleptic test, the panelist prefer fruit leather made from puree mango with formula of puree mango : carrageenan : sorbitol is $90 \%: 0.2 \%: 9.8 \%$. Mango fruit leather was designed in the form of thin elastic sheet with moisture content $24.39 \%$ dan Aw 0,62.
\end{abstract}

Keywords: Carrageenan, fruit leather, mango, binder

\section{INTRODUCTION}

Fruit leather is a food product like a thin sheet which has a unique and constant taste made of a certain kind of fruits. The fruits chosen as the material in the fruit leather production are fruits which consist of high fiber. Fruit leather is a kind of dried sweets which can be produced for commercial purpose or industries through an easy process, squash fruits into pure and drying it out (Raab \& Oehler, 2000).

Fruit leather can be produced from apple, strawberry, sour sop, cherry, grape, jackfruit, mango, kiwi and other kinds of fruits (Ranken \& Kill, 1993). According to Raab and Oehler (2000), fruit leather can be produced from one kind of fruit only or mixed of many kinds of fruits. The food combinations which are usually used in the fruit leather production are apple and blueberry, apricot and apple, plump and jackfruit, banana and apple or lemon, orange and jackfruit (Anon 2006).

So far, there is not any standard fruit leather quality yet. However, good fruit leather consist of $10-20 \%$ moisture, the water activity should be less than 0.7 , the texture was elastic, the skin looks shiny, can be consumed directly, and the color, smell, and taste of the fruits material is strong (Nurlaely 2002). According to Winarti (2008), in the fruit leather production process, the presence of binder will affect the quality of the product especially the texture and appearance. The binders which are usually used in the process are carrageenan, seaweed, alginate, tapioca flour, maizena flour, wheat flour, malto dekstrin, and gelatine. 
Seeweed is one of marine natural resources which can be processed into basic product (as a result of primary metabolite). Hydrocolloid compound made from seaweed is called a ficocolloid compound. Hydrocolloid compound made from seaweed is also the main material of more than 500 commercial products in many industries. The example of hydrocolloid compound made from commercial seaweed in Indonesia is carrageenan (made from karaginofit type), seaweed (made from agarofit type) and alginate (made from alginofit type).

Hydrocolloid compound is really needed in producing a certain product because of the function as gel former, binder, stabilizer, emulsifier, suspensors, and disperser (Anggadiredia et al. 2006). Hydrocolloid compound usually consist of long chain hydrophilic polysaccharide. Carrageenan has been used as gel former combined with konjac in the jelly candy (Subaryono et al., 2006; Sinurat et al., 2008). The use of seaweed as a gel former in producing nori-leather has been tried out by Hasanah (2007) while alginate was used as a hydrocolloid polymer in the production of edible film (Murdinah et al. 2007). In this research, carrageenan was used as the binder in the production of fruit leather, and as an effort in intensifying and optimizing carrageenan production in a country.

Instead of the delicious taste, mango is a source of nutrient which is important for our health. The meat of the mango which has orange color contains vitamin A which is needed for our health. Vitamin A in a mango fruit is about 1.200-16.400 Sl. Instead of vitamin A, mango also contains vitamin $C$ for around $6-30 \mathrm{mg} / 100 \mathrm{~g}, 13-16 \mathrm{mg}$ calcium and 9-10 mg phosphor in each (Suyanti et al. 2006; Setyadiit et al., 2005). So far, mango is usually consumed when it is still fresh. The most widely known product made of mango is dodol mangga. The fact, mango has a big potential to be processed into many kinds of products which has high commercial value such as fruit leather. Fresh mango can be processed into dry sheet (fruit leather) which contains natural fiber and nutrient. Fruit leather production process by changing the saving and serving technique from a simple product into more valuable product is very perspective. Fruit leather which has wide and thin shape is easy to be saved and more durable. The texture is elastic so that it is suitable for children who are difficult to eat fruit.

The purpose of this research is to provide the technique in producing mango fruit leather, to find the suitable concentration of carrageenan for fruit leather production, and to investigate the quality of the fruit leather product. The result of this research is expected to optimize the use of carrageenan in this country, vary the products made of mango, and provide a new product in Indonesia.

\section{MATERIAL AND METHOD}

\section{Material}

Raw material which was used in this research was mango and carrageenan which was resulted from the extraction of seaweed $E$. cottonii based on the extraction method has been 
experimented by Murdinah et al., (2007). Chemical substances were used to analyze the mango quality, carrageenan quality and fruit leather quality.

This research consist of two stages which is preliminary study and main experiment. The preliminary study was intended to find the formula in making fruit leather by studying the composition of the fruit leather. The formulation of the material to make the fruit leather can be seen in the Table 1. The main experiment was intended to try out the use of carrageenan as the binder in the process of fruit leather production. As a comparison, gelatine was used. The binder concetration experimented were $0.2 \%, 0.4 \%, 0.6 \%$. The concentration were chosen based on Winarti (2008).

Table 1. Fruit leather formulation

\begin{tabular}{lccccc}
\hline \multirow{2}{*}{ Bahan } & \multicolumn{5}{c}{ FORMULATION } \\
\cline { 2 - 6 } & Formula A & Formula B & Formula C & Formula D & Control \\
\hline Mango puree & 90 & 90 & 90 & 90 & 90 \\
Sorbitol & 10 & 9.8 & 9.6 & 9.4 & 9.8 \\
Carrageenan & 0 & 0.2 & 0.4 & 0.6 & 0 \\
Gelatin & 0 & 0 & 0 & 0 & 0.2 \\
\hline
\end{tabular}

\section{Procedure in producing fruit leather}

The mango was chosen based on the physiological appearance, which has yellow color but the texture was still hard. The mango was then washed, peeled and the mango meat was taken and blended with water (The comparison of the meat and water was 1:1) so that it become smooth. The blended fruit was boiled so that it become jelly (about 15 minutes). The blended puree was then poured into molding pan and put in the oven with $60^{\circ} \mathrm{C}$ temperature so that it can be rolled like leather (with moisture 10-20\%). This procedure was adapted and modified from Anon (2009).

\section{Analysis}

In this research, binder from carrageenan was characterized. Carrageenan analysis included moisture content, ash content, and acid insoluble ash content by using AOAC method (2005), $\mathrm{pH}$ was measured using $\mathrm{pH}$ meter, the gel streght was measured by using Texture Analyzer (TA-XTPlus) while the viskosity was measured using Brookfield viscometer.

Fruit leather quality analysis includes moisture content (AOAC, 2005), and Aw was measured using Aw meter. Organoleptic test was carried out in terms of physical feature, color, smell, taste, and texture by using hedonic method (Kartika, 1989). The research design which was used in this research was random complete single factor design with 3 times repetition. The treatment which was analyzed was the binder treatment with different concentration of the material (3 different concentration) Steel \&Torrie (1995).

\section{RESULT AND DISCUSSION}

\section{Characteristics of carrageenan as a binder in the process of fruit leather production}

Carrageenan as the result of seaweed $E$. Cottonii extraction based on the extraction method developed by Murdinah et al., (2007) which has $26.72 \%$ rendemen. Carrageenan quality control 
was carried out based on the requirement of export quality standart. Carrageenan analysis included moisture content, ash content, and acid insoluble ash content, $\mathrm{pH}$, gel strength and viscosity. Characteristics of carrageenan as the result of the extraction were shown in the Table 2.

Table 2. Characteristic of carrageenan

\begin{tabular}{lc}
\hline \multicolumn{1}{c}{ Parameters } & Value \\
\hline Moisture content (\%) & 11.46 \\
Ash content (\%) & 16.07 \\
$\mathrm{pH}$ & 8.02 \\
Acid insoluble ash content (\%) & 0.04 \\
Viskosity (cPs) & 111.33 \\
Gel Strength $\left(\mathrm{g} / \mathrm{cm}^{2}\right)$ & 1322.725 \\
\hline
\end{tabular}

\section{Preliminary Study}

The preliminary study was intended to find the formula and composition in producing fruit leather. In the preliminary study, fruit leather production was conducted using the formulation as in Table 3.

Table 3. Fruit leather formulation on the preliminary study

\begin{tabular}{llllllllll}
\hline \multirow{2}{*}{ Material } & \multicolumn{8}{c}{ FORMULATION } \\
\cline { 2 - 10 } & MKA & MKB & MKC & MKD & MKE & MKSA & MKSB & MKSC & MGA \\
\hline Mango Puree & 99.8 & 99.6 & 99.4 & 99.2 & 99.0 & 90 & 90 & 90 & 99.8 \\
Sorbitol & 0 & 0 & 0 & 0 & 0 & 0.2 & 0.4 & 0.6 & 0.2 \\
Carrageenan & 0.2 & 0.4 & 0.6 & 0.8 & 1.0 & 0.2 & 0.4 & 0.6 & 0 \\
Gelatin & 0 & 0 & 0 & 0 & 0 & 0 & 0 & 0 & 0.2 \\
\hline
\end{tabular}

The fruit leather production that was conducted using the formulation as in table 3 can be seen in the Picture 1 and Picture 2.

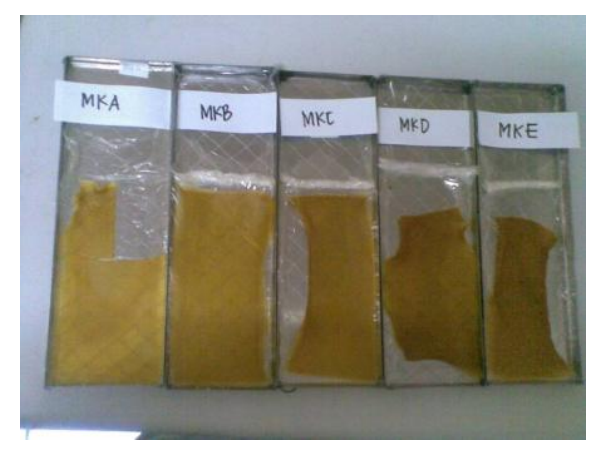

Picture 1. Fruit leather with the manggo puree and carrageenan composition

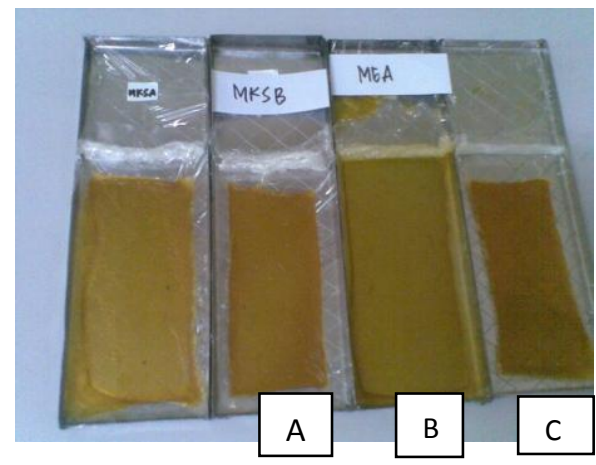

Picture 2. The composition of Fruit leather (A) mango puree, sorbitol, carrageenan (B) mango puree, sorbitol, 0,4\% carrageenan (C) mango puree, sorbitol, gelatin 
As can be seen in the picture 1, fruit leather without sorbitol was shrinkened and become more shrinkened when the concentration of carrageenan was increased. If we compare it to the fruit leather with gelatin, the surface was flat and unshrinkened. While for the fruit leather with sorbitol addition, the surface was flat and the shrinkening only happened in the sides. Based on the descriptive organoleptic test, the formulation that used in the main experiment was the formulation which used carrageenan and sorbitol, where the fruit leather was not changed in term of appearance before and after it was placed in the oven.

\section{Main Experiment}

Based on the preliminary study, the formulation that used was the addition of sorbitol. In the main experiment, the formulation that was used can be seen in the Table 1 with $0.2 ; 0.4$; dan $0.6 \%$ of carrageenan. The number of sorbitol added followed the number of carrageenan added while the number of the puree was constant $90 \%$.

After the mango was peeled, the mango meat remained was about $70,96 \%$. The mango meat was blended with water with 1:1 composition until it became puree. Puree as the main material should be imidiately processed into fruit leather because the color of puree will became brownish yellow very quickly.

The adding and blending of carrageenan and sorbitol was carried out before the boiling process. This process will make the disolving process easier so that the compound became more homogenious so it takes less time to cook, because the longer the cooking period, the colour of the puree become darker and it will make the appearance become unattractive. If the puree which was cooked has been became yellow brownish, the colour of the fruit leather will become darker in the oven. Puree mixture, carrageenan and sorbitol which has been cooked should be quickly poured into moulding pan that had been covered with plastic wrap. The plastic wrap was important to peel the fruit leather. After the mixture was poured into the moulding pan, it was cooled in the room temperature for 1 hour so that it become coagulated, then put it in the oven. The moulding pan size for making the fruit leather is $22 \mathrm{~cm} \times 7 \mathrm{~cm}$.

Fruit leather which had been cooked was dried out for 24 hours in the $60^{\circ} \mathrm{C}$ temperature. Fruit leather that had been dried then being peeled off from the plastic wrap, and covered with cake paper. Fruit leather quality analysis included moisture content (AOAC, 2005), and Aw which was measured using Aw meter. The result of the analysis on the moisture content and Aw can be seen in the Table 4 .

Table 4 showed that the Aw fruit leather, the product categorized as semi wet product. According to Soekarto (1979), semi wet product has Aw about 0,6-0,9 which was quite durable and stable at the room temperature. Aw was the number of the free water which can be used by microba to grow (Syarief dan Halid, 1993). The more the number of the free water in a food product, the bigger chance for biochemistry microbiology and physic reaction happened. Winarno (1990) stated that different kind of microba need different number of water. Generally, micoba can grow in the media with high number of $A w(\geq 9)$, yeast needs 
lower number of Aw (0.8-0.9), and fungi ( $\leq 0.8)$. Buckle et al.(1987) stated that the minimum Aw that was good to grow fungi was 0.80-0.87, while the minimum Aw number for growing yeast was between 0.87-0.91 and bacteria can grow at Aw 0.91.

Table 4. Analysis moisture content and Aw of fruit leather

\begin{tabular}{lccccc}
\hline \multirow{2}{*}{ Parameters } & \multicolumn{6}{c}{ Sample } \\
\cline { 2 - 6 } & A & B & C & D & E \\
\hline Moisture & 14.25 & 24.39 & 11.17 & 12.08 & 17.94 \\
content(\%) & 0.57 & 0.62 & 0.57 & 0.72 & 0.46 \\
Aw &
\end{tabular}

Note: $\mathrm{A}:$ mango puree $:$ carrageenan $:$ sorbitol $=90: 0: 10 ; \mathrm{B}:$ mango puree $:$ carrageenan $:$ sorbitol $=$ $90: 0,2: 9,8 ; C:$ mango puree : carrageenan : sorbitol $=90: 0,4: 9,6 ; D:$ mango puree : carrageenan $:$ sorbitol $=90: 0,6: 9,4 ; \mathrm{E}:$ mango puree $:$ gelatin $:$ sorbitol $=90: 0,2: 9,8$

Organoleptic test includes the appearance, colour, smell, taste, and texture by using hedonic method (Kartika 1989).

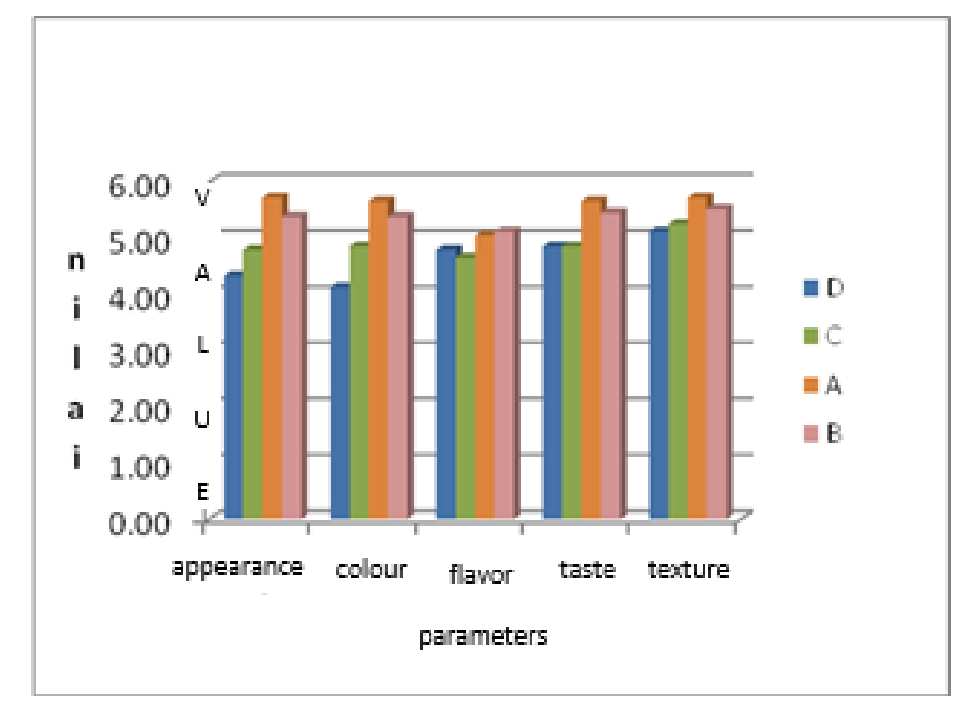

Picture 9. Organoleptic test (Hedonic test) of fruit leather

The result of the organoleptic analysis on the fruit leather showed that the panelist prefer fruit leather with formula A dan B but formula A does not have elastic texture because of the absence of carrageenan as the binder. In this research, the best mango fruit leather is formula B, with $90: 9.8: 0.2$ mixture of puree : sorbitol : carrageenan.

\section{CONCLUSION}

In this research, the technique in producing mango fruit leather has been investigated. Based on the organoleptic test in a hedonic and descriptif method, fruit leather which was prefered by the panelist was the one which has thin and elastic shape (not easy to be torn) and the composition of mango puree : carrageenan : sorbitol is $90: 0.2$ : 9.8 with moisture content $24.39 \%$ and Aw 0,62 . 


\section{REFERENCES}

Anonymous. 2006. Making Fruit leather. http:/Spokane-country.wsu.edu/food/season3.htm. Diakses pada tanggal 31 Oktober 2009.

Anonymous. 2009. Make Your Own Fruit leather. http://www.greenliving suite 101.com. Diakses pada tanggal 2 November 2009.

Anggadiredja, J.T., Zatnika, A., Purwoto, H., dan Istini, S. 2006. Rumput Laut : Pembudidayaan, Pengolahan dan Pemasaran Komoditas Perikanan Potensial. Penebar Swadaya.147pp.

Apriyantono, A., Fardiaz, D., Puspitasari, L., N., Sedarnawati, dan Budiyanto, S. 1989. Analisis Pangan. IPB Press. Bogor. 229 pp.

Hasanah, H. 2007. Nori-leather Imitation Dari Tepung Agar Hasil Ekstraksi Rumput Laut Merah Jenis Gelidium sp. Skripsi. Fakultas Perikanan dan Ilmu Kelautan. Institut Pertanian Bogor.

Kartika, B. 1989. Uji Inderawi Bahan Pangan. PAU Pangan dan Gizi. Universitas Gadjah Mada, Yogyakarta.

Murdinah, M. Darmawan dan D. Fransiska. 2007. Karakteristik Edible Film dari komposit Alginat, Gluten dan Lilin Lebah (Beeswax).Jurnal Pasca Panen Dan Bioteknologi Kelautan Dan Perikanan. Vol.2: 1 8pp.

Nurlaely, E. 2002. Pemanfaatan Buah Jambu Mete untuk Pembuatan Leather. Kajian dari Proporsi Buah Pencampur. Skripsi jurusan Teknologi Hasil Pertanian. Universitas Brawijaya Malang.

Raab, C. and Oehler, N. 2000. Making Dried Fruit leather. Extention Foods and Nutrition Specialist. Origon State University.

Ranken, M.D. and Kill, R.C.1993. Food Industries Mannual. 23 Edition. Blackie Academic and Professional.

Setyadjit, D.A. Setyabudi, dan I. Agustinisari. 2005. Teknologi Pengolahan Puree Mangga. Balai Besar Penelitian Dan Pengembangan Pasca Panen Pertanian. Badan Penelitian Dan Pengembangan Pertanian

Soekarto ST. 1990. Dasar-dasar Pengawasan dan Standarisasi Mutu Pangan. Bogor: PAU Pangan dan Gizi, IPB.

Suyanti, S.Prabawati dan Setyadjit. 2006. Pedoman Teknis Pengolahan Mangga. Balai Besar Penelitian dan Pengembangan Pasca Panen Pertanian. Badan Penelitian dan Pengembangan Pertanian. Departemen Pertanian. 57 pp.

Syarif, R dan Y. Halid. 1993. Teknologi Penyimpanan Pangan. Penerbit Arcan, Bandung.

Utomo, B.S.B., Irianto, H.E., Murdinah, Subaryono, Lestari, D., dan Sinurat, E. 2004. Laporan Teknis Riset Fikokoloid sebagai Subtitusi Pengganti Gelatin. Bagian Proyek Riset Pengolahan Produk dan Sosial Ekonomi Kelautan dan Perikanan. Jakarta.

Winarno, F.G dan B.S.L Jennie. 1983. Kerusakan Bahan Pangan. PT. Gramedia. Jakarta. 